\title{
INFRA-RED THERMOGRAPHY FOR DETECTING DROUGHT IN AGRICULTURAL CROPS AND SCHEDULING IRRIGATION
}

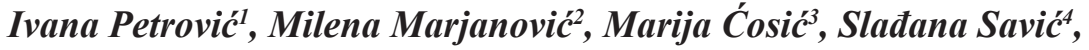 \\ Gorica Cvijanovićs
}

\section{Summary}

The use of thermal imaging is a fast growing and potentially important tool in various fields of agriculture. The technology visually identified the rise of temperature in crop canopy which occurs as a result of drought and allows the precise scheduling of crop irrigation. The aim of presenting paper was to demonstrate the application of these techniques on potato plants and to point out on the necessity of irrigation for potato sustainable and economically justified production.

Key words: Infra-red thermography, potato, drought, irrigation.

JEL: $Q 25$

\section{Introduction}

Climate change is one of the most serious problems facing the world today. The recent Intergovernmental Panel on Climate Change reports confirmed that climate change will have a significant impact on global surface temperature. The projections of IPCC are that the rise of the mean temperature will be as high as $6.4^{\circ} \mathrm{C}$ by 2100 and the number

1 Ivana Petrović, M.A., Ph.D. student, University of Belgrade, Faculty of agriculture, Belgrade, Nemanjina Street no. 6, Belgrade, Republic of Serbia, Phone: +381 6495181 47, E-mail: ivana.petrovic@agrif.bg.ac.rs

2 Milena Marjanović Ph.D., Professor, University of Belgrade, Faculty of agriculture, Belgrade, Zemun, Nemanjina 6, Republic of Serbia, Phone: +381 621120 447, E-mail: milena.pauk@agrif.bg.ac.rs

3 Marija Ćosić, Ph.D., Assistant professor, University of Belgrade, Faculty of agriculture, Belgrade, Nemanjina Street no. 6, Belgrade, Republic of Serbia, Phone: +381 6933145 53, E-mail: cosic.marija661@gmail.com

4 Slađana Savić, PhD, Associate professor, John Naisbitt University Belgrade, Faculty of biofarming, Maršala Tita street no. 39, 24300 Bačka Topola, Republic of Serbia, Phone: +38160443 46 15, E-mail: bonita.sladja@gmail.com

5 Gorica Cvijanović, PhD, Full Professor, John Naisbitt University Belgrade, Faculty of biofarming, Bačka Topola, 24300 Bačka Topola, Maršala Tita street no. 39, Republic of Serbia, Phone: +381 6924060 36, E-mail: cvijagor@yahoo.com

EP 2016 (63) 2 (461-469) 
of extreme events, including heat waves, storms and flooding will increase (IPCC, 2007). The especially vulnerable for future European summer climate would be the countries in South-East European and Mediterranean areas. Predictions of different scenarios of climate are that due to the expected increase in temperature and decrease in precipitation, drought would start earlier and last longer in these comparing to other European areas (Beniston et al., 2007).

Agriculture is highly sensitive to climate change and especially, to drought. Study for Southern Europe predicted by 2050 a general yield decreases for different crops up to $30 \%$, as well as increases in water demand up to at least 10\% (Alcamo et al., 2007). Although drought in South East European region is shorter than in Mediterranean, its impact on agricultural production in South East European region, including Serbia, could be very serious. During summer period growth and productivity of a lot of agricultural plants are in the most sensitive phase to drought, and therefore, the reduction of yield could be significant. In such climatic conditions the economically profitable production could be achieved by irrigation (Jovanović, Stikić, 2012). However, in Serbia similar to other South East European countries, only a small proportion of the arable land (only $3.7 \%$ ) is equipped for irrigation (Kresović et al., 2014).

Results of Kresović et al. (2014) showed that irrigation increased maize yields by 4.8$48 \%$ (average 18.7\%) independence of weather conditions. Their economic assessment confirmed higher profitability of irrigated maize (841.79 EUR/ha vs. rain-fed 699.35 EUR/ha). Irrigation increased overall costs by $10.75 \%$ and profits by $21.4 \%$, compared to rain-fed conditions. Their calculation also showed that the estimated average annual loss incurred in Serbia due to a lack of irrigation in maize production is 122,161.287 EUR.

Due to the increased competitions for water resources between different sectors (agriculture, industry or domestic consumption) in many countries, the challenge is to increase agricultural productivity per unit of water ("more crop per drop"), and to use optimally irrigation in accordance with the crop`s needs (Luquet et al., 2005).

The current concept of proper irrigation scheduling is based on the use of high techtechnologies as infra red thermography. Infrared (IR) thermal imaging technique (also known as IR thermography or imaging IR radiometry), permits to measure IR radiation emitted by objects at ambient temperature over a large amount of points and processing these measurements to form a thermal map of the target surface (Jones, 2004, Costa et al., 2013). The ITR is a non-invasive, non-contact and non-destructive technique used to determine thermal properties and features of any object of interest and therefore it can be used for identification of plant temperature that rise as a results of drought or heat stress (González-Dugo et al., 2006) and allows the precise scheduling of crop's irrigation.

In Serbia IRT has not yet been explored for irrigation and the aim of this paper was to demonstrate the application of this technique on potato plants and to point out on the necessity of irrigation for potato sustainable production. The potato was chosen for demonstration as leading vegetable crop and the $4^{\text {th }}$ most important food crop (after 
rice, wheat and maize) worldwide (FAOSTAT, 2012) and also very important vegetable for Serbian agriculture.

\section{Material and method}

The IRT method was tested in potato (Solanum tuberosum L.) cultivar Liseta. The test was done in the vegetative phase of potato plant growth when they were exposed to drought (excluded irrigation) and full irrigation.

An infrared thermal imaging system comprises of a thermal camera equipped with infrared detectors, a signal processing unit and an image acquisition system. In our experimental system leaf temperature was measured by using a thermal camera (ThermaCAM B20). This camera supplies infrared spectrum images of high quality, allowing accurate temperature measurement, with an infrared pixel resolution of 320 $\times 240$, and $\pm 0.2^{\circ} \mathrm{C}$ thermal resolution. Thermal images were analyzed by using the FLIR Quickreporter image analysis software. Control of plant water status was done by pressure chamber and water potential values were used as control parameters for plant water status.

The statistical analyses were performed with SigmaPlot software (version 11.0) using Student's t-test.

\section{Results and discussion}

False-colored IR thermal images showed differences between leaves of potato plants exposed to drought and optimally irrigated (Fig.1). Visually the leaves differed in a such way that more yellow and red color of the leaves indicated heat stress in the leaves, while more dark color optimal water conditions. Our thermal imaging are presented as black/white photos, and t lighter color leaves indicates a higher temperature of leaves, or a greater degree of drought stress where the leaves are exposed. On the contrary, darker color indicate the optimal leaf water regime.

Figure 1. Thermal image of two potato plants irrigated (left) and non-irrigated (right) taken with a ThermaCAM B20

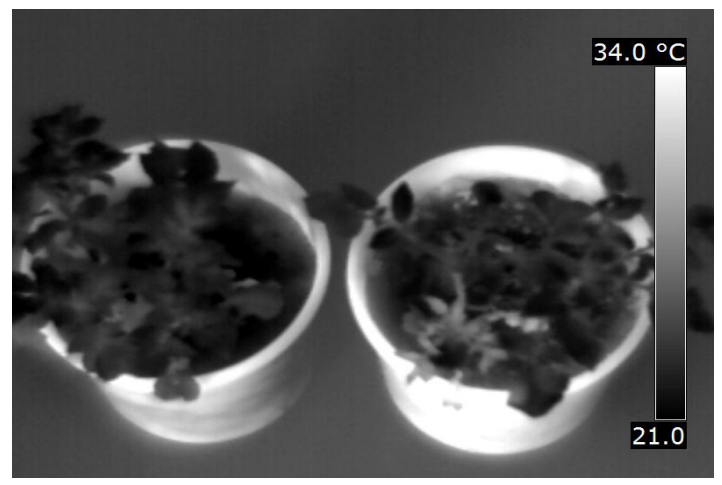

Source: Photographer-Milena Marjanović

EP 2016 (63) 2 (461-469) 
The temperature of optimally irrigated plants was $21.7^{\circ} \mathrm{C}$ and of the leaves in plants exposed to drought about $22.9^{\circ} \mathrm{C}$ (Table1). Measurements of leaf water potential, as parameter of water status (Table1), confirmed that non-irrigated plants were exposed to mild drought stress conditions $(-1.0 \mathrm{MPa})$ compared to the control plants $(-0.4 \mathrm{MPa})$. The thermal imaging confirmed results obtained by measuring plant water regime parameters.

Table 1. Leaf temperature and leaf water potential in irrigated and non-irrigated potato plants

\begin{tabular}{|l|l|l|}
\hline Parameters & irrigated & non-irrigated \\
\hline Leaf temperature $\left({ }^{\circ} \mathbf{C}\right)$ & $21.7 \pm 0.3$ & $22.9 \pm 0.3$ \\
\hline Leaf water potential (MPa) & $-0.4 \pm 0.03$ & $-1.0 \pm 0.05$ \\
\hline
\end{tabular}

Source: Work of authors based on research results

Thus, obtained results confirmed that IR image, as a simple color identification technique, could be very useful for identification of drought stress in potato. This is of special importance for potato because the potato is grown in different agro-ecological regions, but it is best adapted to temperate climate and frost-free seasons and therefore is very sensitive to both high temperatures and drought. Optimum mean daily temperatures for potato production are 18 to $20^{\circ} \mathrm{C}$, while a night temperature of below $15^{\circ} \mathrm{C}$ is required for tuber initiation. High temperatures and even short periods of drought stress can cause significant reductions in tuber yield and quality (Onder et al., 2005, Jovanović et al., 2012).

In Serbia potato is growing in the area of 76.500 ha, and only $12-15 \%$ of this area is irrigated (Broćić, Stefanović, 2012). The yield of potato in Serbia is fourth times lower than this achieved in the leading potato growing countries (Germany 45 $\mathrm{t} \mathrm{ha}^{-1}$, France $45 \mathrm{t} \mathrm{ha}^{-1}$, Belgium $44 \mathrm{t} \mathrm{ha}^{-1}$ ). The low yields are the consequence of inadequate management practices, insufficient amount and unfavorable arrangement of precipitation during the growing season and inappropriate irrigation scheduling applied (Pejić et al., 2015). The results of Pejić et al. (2015) confirmed that potato is moderately sensitive to soil water stress in the climatic conditions of the Southern Serbia where seasonal evapotranspiration were $495.0 \mathrm{~mm}$ and $291.2 \mathrm{~mm}$ in irrigated and rain-fed conditions and with irrigation the yield could achieve $48.31 \mathrm{t} \mathrm{ha}^{-1}$ or $88.3 \%$ higher than in the rain-fed conditions.

In Table 2 are presented the results of the effects of irrigation and rain-fed conditions on the average yield and profit of potato production in the period between 2008 and 2013. These results also included 2012 year when because of extremely dry conditions in Serbia the rain-fed potato production recorded a loss. They confirmed the importance of irrigation for profitable potato production. 
Table 2. The average yield $(\mathrm{t} / \mathrm{ha})$ and profit $(€ /$ ha) for potato production in Serbia for the period between 2008 and 2013 year

\begin{tabular}{|l|l|l|}
\hline Item & Rain-fed condition & Irrigation \\
\hline Yield & 22.5 & 42.4 \\
\hline Profit & 1797 & 4872 \\
\hline
\end{tabular}

Source: Work of authors based on research results

The profitability of potato irrigation also depends on the irrigation methods. Potatoes are most often irrigated by furrow, sprinkler and drip methods. Worldwide, drip irrigation is preferred because of higher yields and better tuber quality, and because it uses less water than other methods. The results of Ørum et al. (2010) and Matović et al (2016) also confirmed that subsurface drip irrigation was more profitable than sprinkler irrigation.

Matović et al. (2016) made calculation on the potato production losses in the period between 2011 and 2013. Given that the average area of potato farmland in Serbia was 76,500 ha and that only some $12-15 \%$ of that farmland was irrigated, the following potato production losses were incurred at the national level: $€ 131$ million under rain-fed conditions, compared to sprinkler irrigation; $€ 240$ million under rain-fed conditions, compared to subsurface drip irrigation and $€ 62$ million with sprinkler irrigation, compared to subsurface drip irrigation.

Another aspect of potato irrigation, similarly to the irrigation of other crops, should be taken into consideration is timing for irrigation. Optimal and economically justified irrigation should be applied in the period when the needs of water for plant growth are maximal and in the period when evapotranspiration is less than optimal for potato. Such approach needs the appropriate indicator of crop water status and needs for irrigation. The current results confirmed that thermal imaging or so called „IR thermometers-IRT“ have bigger advantages over soil water content measurements to schedule irrigation.

However, there is no publish results for the use of IRT as an indicator for irrigation timing of potato. Results for other agricultural plants, including almond orchards (Garcia -Trejo et al., 2012) grapevine (Möller et al., 2007; Grant et al., 2007; Bajula et al., 2012) and olive trees (Ben-Gal et al., 2009) confirmed that infrared thermography is a suitable technique for assessing the crop-water status. These and other similar results confirmed that ITR can be used as an important indicator of the precise time and the amount of water that should be applied for irrigation. IRT also allows detection of any problems in watering - such as missed syphons or incomplete irrigation runs - to be identified which may otherwise not have been detected.

The use of thermal imaging is a fast growing and potentially important tool in various fields of agriculture. Currently, in precise farming production the thermal remote sensing in agriculture includes also nursery and greenhouse monitoring, plant disease detection, estimating fruit yield, evaluating the maturity of fruits and bruise detection 
in fruits and vegetables (Ishimwe et al., 2014). Monitoring the fields could be done in different ways, including ground-based remote sensing (attached to the GPS-referenced tractor) or airborne sensors (from satellite, drone, airplane).

Very recently agricultural drones are in the use for precise farming in developed countries (http://dronelife.com/agriculture-drones/). With advanced sensors and imaging capabilities they are giving farmers new ways to increase yields and reduce crop damage (induced by drought, salt stress, pathogens, nutrient deficiency etc.). Compared with satellite imagery, they are much cheaper in USA (less than $\$ 1,000$ each), they offer higher resolution and can survey a crop every week, every day, or even every hour.

\section{Conclusion}

The use of thermal imaging is a fast growing and potentially important tool in various fields of agricultural management, including irrigation. Application of this high techtechnologies are of special interest in the countries, such as Serbia, facing with the challenges of increased demand for the use of water for agricultural production and the necessity to save existing water resources for other consumers (industry or domestic consumption).

\section{References}

1. Alcamo, J., Moreno, J. M., Nováky, B., Bindi, M., Corobov, R., Devoy, R. J. N., Giannakopoulos, C., Martin, E., Olesen, J. E., Shvidenko, A. (2007): Europe. Climate Change 2007: Impacts, Adaptation and Vulnerability. Contribution of Working Group II to the FourthAssessment Report of the Intergovernmental Panel on Climate Change, Parry, M. L., Canziani, O. F., Palutikof, J. P., van der Linden, P. J., Hanson, C. E. (Ed.), ISBN 9780521 88010-7. 541-580, Cambridge University Press, Cambridge, UK.

2. Baluja, J., Diago, M. P., Zorer, R., Meggio, F., Tardaguila, J. (2012): Assessment of vineyard water status variability by thermal and multispectral imagery using an unmanned aerial vehicle (UAV). Irrigation Science, Springer, year 2012, no. 30, pp. 511-522, Netherlands.

3. Ben-Gal, A., Agam, N., Alchanatis, V., Cohen, Y., Yermiyahu, U., Zipori, I., Presnov, E., Sprintsin, M., Dag, A. (2009): Evaluating water stress in irrigated olives: correlation of soil water status, tree water status, and thermal imagery. Irrigation Science, Springer, no. 27 , pp. 367-376, Netherlands.

4. Beniston, M., Stephenson, D. B., Christensen, O. B., Ferro, C. A .T., Frei, C., Goyette, S., Halsnaes, K., Holt, T., Jylhä, K., Koffi, B., Palutikof, J., Schöll, R., Semmler, T., Woth, K. (2007): Future extreme events in European climate: an exploration of regional climate model projections. Climatic Change, Springer, vo. 81, no. 1, pp. 7195, Netherlands.

5. Broćić, Z., Stefanović, R. (2012): Potato, production, cost-effectiveness and market (in Serbian). University of Belgrade, Faculty of Agriculture, Zemun. 
6. Costa, J. M., Grant, O. M., Chaves, M. M. (2013): Thermography to explore plantenvironment interactions. Journal of Experimental Botany, Oxford University Press, vol. 64, pp. 3937-3949, Oxford, UK.

7. FAOSTAT, (2012): (www. faostat.fao.org).

8. García-Tejero, I., Duràn-Zuazo, V.H., Arriaga, J., Hernàndez, A., Vélez, L.M., MurielFernàndez. J.A. (2012): Approach to assess infrared thermal imaging of almond trees under water-stress conditions. Fruits, EDP Sciences, vol. 67, pp. 463-474, London, UK.

9. González-Dugo, M.P., Moran, M.S., Mateos, L., Bryant, R. (2006): Canopy temperature variability as an indicator of crop water stress severity. Irrigation Science, Springer, vol. 24, pp. 233-240, Netherlands.

10. Grant, O.M., Tronina, L., Jones, H.G., Chaves, M.M. (2007): Exploring thermal imaging variables for the detection of stress responses in grapevine under different irrigation regimes. Journal of Experimental Botany, Oxford University Press, vol. 58, pp. 815-825, Oxford, UK.

11. IPCC (2007): Climate Change 2007: Impacts, Adaptation, and Vulnerability. Contribution of Working Group II to the Third Assessment Report of the Intergovernmental Panel on Climate Change. Parry, M. L., Canziani, O. F., Palutikof, J. P., van der Linden, P. J., Hanson, C.E. (Ed.), ISBN 9780521 88010-7. 976, Cambridge University Press, Cambridge, UK.

12. Ishimwe, R., Abutaleb, K., Ahmed, F. (2014): Applications of Thermal Imaging in Agriculture-A Review. Advances in Remote Sensing, Scientific Research Publishing, no. 3, pp. 128-140, Wuhan, China.

13. Jones, H. (2004): Application of thermal imaging and infrared sensing in plant physiology and ecophysiology. Advances in Botanical Research, Elsevier Ltd., 2004, no. 41, pp. 107-163, Amsterdam, Netherlands.

14. Jovanović, Z., Stikić, R. (2012): Strategies for Improving Water Productivity and Quality of Agricultural Crops in an Era of Climate Change. In book: Irrigation Systems and Practices in Challenging Environments, Ed., ISBN 978-953-51-0420-9. Teang Shui Lee, InTech., pp. 77-102, Rijeka, Croatia.

15. Jovanović, Z., Stikić, R., Brocić, Z., Oljača, J. (2012): Climate Change: Challenge for Potato Production in South-East Europe. In: Potatoes: Production, Consumption and Health Benefits, ISBN 978-1-62100-703-6. Ed. Claudio Caprara, Nova Science Publishers, pp. 37-66, New York, USA.

16. Kresović, B., Matović, G., Gregorić, E., Đuričin S., Bodroža, D. (2014): Irrigation as a climate change impact mitigation measure: An agronomic and economic assessment of maize production in Serbia. Agricultural Water Management, Elsevier Ltd., 2014 vol. 139, pp. 7-16, Amsterdam, Netherlands.

17. Luquet, D., Vidal, A., Smith, M., Dauzat, J. (2005): 'More crop per drop': how to make it acceptable for farmers? Agricultural Water Management, Elsevier Ltd., 2005 vol. 
76, no. 2, pp. 108-119, Amsterdam, Netherlands.

18. Matović, G., Broćić, Z., Đuričin, S., Gregorić, E., Boroža, D. (2016): Profitability assessment of potapo production applying different irrigation methods. Irrigation and Drainage, Wiley, 2016 (DOI: 10.1002/ird.1983), Hoboken, New York, USA.

19. Möller, M., Alchanatis, V., Cohen, Y., Meron, M., Tsipris, J., Naor, A., Ostrovsky, V., Sprintsin, M., Cohen, S. (2007): Use of thermal and visible imagery for estimating crop water status of irrigated grapevine. Journal of Experimental Botany, Oxford University Press, vol. 58, pp. 827-838, Oxford, UK.

20. Onder, S., Caliskan, M.E., Onder, D., Caliskan, S. (2005): Different irrigation methods and water stress effects on potato yield and yield components Agricultural Water Management, Elsevier Ltd., vol. 73, pp. 73-86, Amsterdam, Netherlands.

21. Ørum, J.E, Boesen, M.V, Jovanović, Z., Pedersen, S.M. (2010): Farmers' incentives to save water with new irrigation systems and water taxation - A case study of Serbian potato production. Agricultural Water Management, Elsevier Ltd., vol. 98, pp. 465471, Amsterdam, Netherlands.

22. Pejić, B., Aksić, M., Mačkić, K., Šekularac, G. (2015): Response of Potato to Water Stress in Southern Serbia. Austin Journal of Irrigation, Austin Publishing Group, vol. 1, no. 1, pp. 1-4, New Jersey, USA. 


\title{
INFRA-CRVENA TERMOGRAFIJA ZA DETEKCIJU SUŠE U POLJOPRIVREDNIM USEVIMA I PLANIRANJU NAVODNJAVANJA
}

\author{
Ivana Petrovićc ${ }^{6}$ Milena Marjanovič ${ }^{7}$, Marija Ćosić ${ }^{8}$, Slađana Savic ${ }^{9 *}$ \\ Gorica Cvijanovic ${ }^{10}$
}

\begin{abstract}
Sažetak
Korišćenje termalne infra-crvene termografije je u ekspanziji i sve više nalazi primenu u različitim oblastima poljoprivrede. Ovom tehnologijom se može vizuelno identifikovati porast temperature kod biljaka izloženih suši i to zatim omogućava precizno planiranje i optimalnu primenu navodnjavanja. Cilj ovog rada je da se demonstrira primena ovih tehnologija na biljkama krompira i da se ukaže na neophodnost navodnjavanja u održivoj i ekonomski opravdanoj proizvodnji krompira.
\end{abstract}

Ključne reči: Infra-crvena termografija, krompir, suša, navodnjavanje.

6 Master Ivana Petrović, doktorant, Univerzitet u Beograd, Poljoprivredni fakultet, Nemanjina ulica br. 6, Beograd, Srbija, Telefon: +381 6495181 47, E-mail: ivana.petrovic@agrif.bg.ac.rs

7 Profesor, dr Milena Marjanović, Univerzitet u Beograd, Poljoprivredni fakultet, Nemanjina ulica br. 6, Beograd, Srbija, Telefon: +381 621120 447, E-mail: milena.pauk@agrif.bg.ac.rs

8 Docent, dr Marija Ćosić, Univerzitet u Beograd, Poljoprivredni fakultet, Nemanjina ulica br. 6, Beograd, Srbija, Telefon: +381 6933145 53, E-mail: cosic.marija661@gmail.com

9 Vanredni profesor, dr Slađana Savić, John Naisbitt Univerzitet u Beogradu, Fakultet za biofarming, Ulica Maršala Tita br. 39, 24300 Bačka Topola, Republika Srbija, Telefon: +381 60 44346 15, E-mail: bonita.sladja@gmail.com

10 Redovni profesor, dr Gorica Cvijanović, John Naisbitt Univerzitet u Beogradu, Fakultet za biofarming, Ulica Maršala Tita br. 39, 24300 Bačka Topola, Republika Srbija, Telefon: +381 69 24060 36, E-mail: cvijagor@yahoo.com

EP 2016 (63) 2 (461-469) 